\title{
ENVIRONMENTAL IMPACT ASSESSMENT OF FISH DISEASES ON FISH PRODUCTION
}

\author{
M K Hossain ${ }^{1}$, K T Islam² M D Hossain ${ }^{3}$ and M H Rahman ${ }^{4}$
}

\begin{abstract}
The present research work was conducted from July 2008 to June 2009 to investigate intensity of infestation of parasites in freshwater fishes and the impact of fish diseases on fish production in northern region of Bangladesh. Possibility of out break of diseases due to deterioration of environmental factors of water bodies was included in this study. The diseases identified were ulcer diseases, EUS (Epizootic Ulcerative Syndrome), Ichthyophthiriasis, Trichodiniasis, Chilodoneliasis, Myxoboliasis, Dactylogyrosis, Gyrodactylosis, Argulosis, Pernicious anaemia, Red spot disease, Red Pest of freshwater eel, Mouth fungus, Branchiomysis, Abdominal dropsy and whirling disease. The infestation more occurred in young fishes than in adult fishes. The overall water qualities of water bodies fluctuated from July 2008 to June 2009. Physicochemical parameters have more or less significant combined effect on the deterioration of water quality as well as fish diseases. Gills were the most affected sites and parasites damaged gill filaments by rupturing blood capillaries, causing necrosis, coagulation and hemorrhage. The present study revealed the prevalence of different organisms in fishes, which are potential pathogen for them. Fishes were infested by parasites and other pathogens. From overall study it was observed that the parasites, bacteria and fungus were most important pathogen for outbreak of diseases. It was also observed that there was a direct relation between disease outbreak among fishes and environmental factors. Low alkalinity reduces the buffer capacity of water and badly affects the pond ecosystem, which in turn cause stress to the fish and become more susceptible to diseases. In case of low aquatic environmental temperature fish reduces metabolic activities, which in turn makes the fish more susceptible during the winter period towards parasitic infection.
\end{abstract}

Keywords: Environment, Impact, Fish, Disease, Production

\section{INTRODUCTION}

In spite of tremendous potential production, fishery industry has been suffering from out break of diseases. The normal growth of fishes is interrupted or inhibited if they are heavily infected with ectoparasites or endo-parasites, and these parasites, like those of other vertebrates feed either on the digested content of the host's intestine or the host's own tissue (Markov, 1946). Tripathi el al (1978) estimated the losses due to mortality and retardation / cessation of growth of fish in ponds in west Bengal as a result of epidemic infections. Disease is considered to be one of the important factors to decrease the fish production both in farming system and in wild condition. The death of fish caused by disease is of highest significance in fish culture; hence to achieve healthy fish stock we have to keep

\footnotetext{
${ }^{1}$ Institute of Biological Sciences, University of Rajshahi, Rajshahi, Bangladesh, drmkh.du@gmail.com

${ }^{2}$ Bangladesh Chemical Industries Corporation College, Mirpur, Dhaka, Bangladesh

${ }^{3}$ Department of Fisheries, University of Rajshahi, Rajshahi, Bangladesh

${ }^{4}$ Department of Zoology, University of Rajshahi, Rajshahi, Bangladesh
} 
maintenance of health relationship between fish and their environment. Heavy parasitic infection to carp fry increase mortality reduces growth and survival of fry and fingerlings (Shariff and Vijiarungam, 1986). The physiological and biological features of the host affect the composition of parasite (Dogiel, 1961). Diseases at times assume the magnitude of epidemics. Fish pathogens cause significance loss to wild and cultured freshwater fishes. Large-scale mortality of fish often occurs in ponds and tanks due to environmental stress followed by parasitic afflictions and bacterial, viral, fungal, protozoan and monogenean infections. When ecto-parasites or endo-parasites heavily infect the fishes, the normal growth of them is interrupted or inhibited, and these parasites, like those of other vertebrates feed either on the digested content of the host's intestine or the host's own tissue (Markov, 1946). Trpathi et al (1978) estimated the losses due to mortality and retardation / cessation of growth of fish in ponds in west Bengal as a result of epidemic infections. Parasites cause deterioration in the food value of fish and may even result in their mortality. The occurrence of parasites of fresh water fishes in the form of epidemic is a great threat to the major protein supply in Bangladesh. It is not only disturbing the supply of protein but also brings about a bad impact on our country's economy. In Bangladesh the common fish diseases are ulcer type disease including epizootic ulcerative syndrome, tail and fin rot, bacterial gill rot, dropsy, fungal diseases and parasitic diseases (Chowdhury, 1993). Under these circumstances, we have to take several steps towards finding effective solutions to prevent spread of aquatic animal disease. Measure of disease prevention and health management in fish culture has to be taken. Since the disease has tremendous impact on fish production, consumption, and trade and aquaculture practice in the country, it is necessary to investigate the true causal pathogen and pathogenecity etc. of the disease.

\section{MATERIALS AND METHODS}

During the survey on fish production statistics 20 nursery operators, 40 fish farmers and 40 fishermen from each of the study areas were interviewed for production statistics. All total 80 nursery operators, 160 fish farmers and 160 fishermen, in total 400 persons were interviewed during the period of investigation. The survey was done through questionnaire and participatory rural appraisal methods in four districts in northern region namely Rajshahi, Naogaon, Natore and Bogra districts. The research work was conducted during July 2008 to June 2009. The water quality was measured with the filed Hach Kit. Disease was observed with naked eyes first, then by magnifying glass and by the movement and behavior. After having removed the fish from the water, the colour of the body was noted. The skin was always examined with a magnifying glass. It was determined whether there were deformities of the vertebral column and of the mandibles, or perforation and /or shortening of the opercula. Finally the anus was examined for any swelling, and the texture of the muscle was determined to see whether any ulcer or inflammation were present. The diseases were identified according to the methods of Amlacher(1961).

\section{RESULTS AND DISCUSSION}

Fish disease has got inverse impacts on fisheries resources. Economic losses due to fish diseases were investigated. At present fish parasites and other pathogen are causing heavy economic loss due to mortality and morbidity of carp brood stock. Infected market size fish may become unsuitable for human consumptions due to heavy infestation causing serious economic loss to the poor farmers. The impacts of diseases on fisheries resources are presented in Tables from 1 to 5. During the period of 
July 2008 to June 2009 the average optimum fish production in pond is recorded $3705 \mathrm{Kg} / \mathrm{ha}$ and that of in beel and river is $380 \mathrm{Kg} / \mathrm{ha}$ in Rajshahi area. Average fish production loss due to different type of diseases like bacterial, fungal, protozoan, monogenean, crustacean, Malnutrition, $\mathrm{O}_{2}$ deficiency and water pollution is $58.10 \%, 32.60 \%, 46.0 \%, 44.0 \%, 37.70 \%, 15.30 \%, 19.40 \%$ and $24.90 \%$ respectively and over all loss $34.25 \%$ (Table 1). In Naogaon area the average optimum fish production in pond is recorded $3952 \mathrm{Kg} / \mathrm{ha}$ and that of in beel and in river is $402 \mathrm{Kg} / \mathrm{ha}$ during the period of July 2008 to June 2009. Average fish production loss due to diseases of bacteria, fungus, protozoa, monogenea, Crustacea, Malnutrition, $\mathrm{O}_{2}$ deficiency and water pollution is $51.37 \%, 30.06 \%, 36.40 \%, 32.84 \%$, $31.16 \%, 12.86 \%, 15.94 \%$ and $22.38 \%$ respectively and over all loss $29.12 \%$ (Table 2). During the period of July 2008 to June 2009 the average optimum fish production in pond is recorded $3750 \mathrm{Kg} / \mathrm{ha}$ and that of in beel and river is $370 \mathrm{Kg} / \mathrm{ha}$ in Natore area. Average fish production loss due to different type of diseases like bacterial, fungal, protozoan, monogenean, crustacean, Malnutrition, 62 deficiency and water pollution is $56.84 \%, 31.92 \%, 42.69 \%, 40.92 \%, 33.18 \%, 15.17 \%, 19.25 \%$ and $24.34 \%$ respectively and over all loss 33.04\% (Table 3). In Bogra district the average optimum fish production in pond is recorded $3815 \mathrm{Kg} / \mathrm{ha}$ and that of in beel and in river is $390 \mathrm{Kg} / \mathrm{ha}$ during the period of July 2008 to June 2009. Average fish production loss due to diseases of bacteria, fungus, protozoa, monogenea, Crustacea, Malnutrition, $\mathrm{O}_{2}$ deficiency and water pollution is $64.01 \%$, 38.69\%, 47.27\%, 51.45\%, 38.24\%, 17.44\%, 21.77\% and 25.18\% respectively and over all loss $38.0 \%$ (Table 4). Average mortality of fingerlings was $36.5 \%$ and adult fish was $40.75 \%$. Average fingerlings and adult was $38.62 \%$ (Table 5)

Table 1: Depletion of Fish production due to fish disease and water pollution in Rajshahi

\begin{tabular}{|l|c|c|c|c|c|}
\hline \multirow{2}{*}{$\begin{array}{c}\text { Type of Disease } \\
\text { /other factor }\end{array}$} & \multicolumn{2}{|c|}{$\begin{array}{c}\text { Optimum production of } \\
\text { fish (Kg/h) }\end{array}$} & \multicolumn{2}{c|}{$\begin{array}{c}\text { Production loss (due to disease) } \\
\text { (Kg/h) }\end{array}$} & $\begin{array}{c}\text { Average loss } \\
\text { (\%) }\end{array}$ \\
\cline { 2 - 6 } & Pond & Beel \& River & Pond & Beel \& River & \\
\hline Bacterial disease & 3705 & 380 & 2223 & 150 & 58.10 \\
\hline Fungal disease & 3705 & 380 & 1235 & 96 & 32.60 \\
\hline Protozoan disease & 3705 & 380 & 1741 & 140 & 46.0 \\
\hline Monogenean & 3705 & 380 & 1667 & 130 & 33.70 \\
\hline Crustacean & 3705 & 380 & 1296 & 80 & 15.30 \\
\hline Malnutrition & 3705 & 380 & 555 & 70 & 19.40 \\
\hline $\mathrm{O}_{2}$ deficiency & 3705 & 380 & 741 & 50 & 24.90 \\
\hline Water pollution & 3705 & 380 & 926 & 90 & \\
\hline Mean & 3705 & 380 & 1298 & 100.75 & \\
\hline
\end{tabular}


Table 2: Depletion of Fish production due to fish disease and water pollution in Naogaon

\begin{tabular}{|l|c|c|c|c|c|}
\hline \multirow{2}{*}{$\begin{array}{c}\text { Type of Disease } \\
\text { lother factor }\end{array}$} & \multicolumn{2}{|c|}{$\begin{array}{c}\text { Optimum production of } \\
\text { fish (Kg/h) }\end{array}$} & \multicolumn{2}{c|}{ Production loss (due to disease) } & Average loss \\
(Kg/h) & (\%) \\
\cline { 2 - 6 } & Pond & Beel \& River & Pond & Beel \& River & \\
\hline Bacterial disease & 3952 & 402 & 2115 & 122 & 51.37 \\
\hline Fungal disease & 3952 & 402 & 1224 & 85 & 30.06 \\
\hline Protozoan disease & 3952 & 402 & 1470 & 115 & 36.40 \\
\hline Monogenean & 3952 & 402 & 1310 & 120 & 32.84 \\
\hline Crustacean & 3952 & 402 & 1285 & 72 & 31.16 \\
\hline Malnutrition & 3952 & 402 & 495 & 65 & 12.86 \\
\hline $\mathrm{O}_{2}$ deficiency & 3952 & 402 & 630 & 64 & 22.38 \\
\hline Water pollution & 3952 & 402 & 890 & 85 & \\
\hline Mean & 3952 & 402 & 1177 & 91 & \\
\hline
\end{tabular}

Table 3: Depletion of Fish production due to fish disease and water pollution in Natore

\begin{tabular}{|l|c|c|c|c|c|}
\hline $\begin{array}{c}\text { Type of Disease } \\
\text { /other factor }\end{array}$ & $\begin{array}{c}\text { Optimum production } \\
\text { of fish (Kg/h) }\end{array}$ & \multicolumn{2}{c|}{$\begin{array}{c}\text { Production loss (due to } \\
\text { disease) (Kg/h) }\end{array}$} & $\begin{array}{c}\text { Average loss } \\
\text { (\%) }\end{array}$ \\
\cline { 2 - 6 } & Pond & Beel \& River & Pond & Beel \& River & \\
\hline Bacterial disease & 3750 & 370 & 2212 & 130 & 56.84 \\
\hline Fungal disease & 3750 & 370 & 1220 & 95 & 42.92 \\
\hline Protozoan disease & 3750 & 370 & 1635 & 124 & 40.92 \\
\hline Monogenean & 3750 & 370 & 1558 & 128 & 33.18 \\
\hline Crustacean & 3750 & 370 & 1285 & 82 & 15.17 \\
\hline Malnutrition & 3750 & 370 & 552 & 73 & \\
\hline O $_{2}$ deficiency & 3750 & 370 & 741 & 52 & \\
\hline
\end{tabular}




\begin{tabular}{|l|c|c|c|c|c|}
\hline Water pollution & 3750 & 370 & 915 & 88 & 24.34 \\
\hline Mean & 3750 & 370 & 1264.75 & 96.5 & 33.04 \\
\hline
\end{tabular}

Table 4: Depletion of Fish production due to fish disease and water pollution in Bogra

\begin{tabular}{|c|c|c|c|c|c|}
\hline \multirow[t]{2}{*}{$\begin{array}{l}\text { Type of Disease } \\
\text { /other factor }\end{array}$} & \multicolumn{2}{|c|}{$\begin{array}{c}\text { Optimum production } \\
\text { of fish }(\mathrm{Kg} / \mathrm{h})\end{array}$} & \multicolumn{2}{|c|}{$\begin{array}{l}\text { Production loss (due to } \\
\text { disease) }(\mathrm{Kg} / \mathrm{h})\end{array}$} & \multirow[t]{2}{*}{$\begin{array}{c}\text { Average loss } \\
(\%)\end{array}$} \\
\hline & Pond & Beel \& River & Pond & Beel \& River & \\
\hline Bacterial disease & 3815 & 390 & 2520 & 170 & 64.01 \\
\hline Fungal disease & 3815 & 390 & 1510 & 116 & 38.69 \\
\hline Protozoan disease & 3815 & 390 & 1825 & 162 & 47.27 \\
\hline Monogenean & 3815 & 390 & 2010 & 152 & 51.45 \\
\hline Crustacean & 3815 & 390 & 1505 & 102 & 38.24 \\
\hline Malnutrition & 3815 & 390 & 653 & 80 & 17.44 \\
\hline $\mathrm{O}_{2}$ deficiency & 3815 & 390 & 850 & 65 & 21.77 \\
\hline Water pollution & 3815 & 390 & 960 & 98 & 25.18 \\
\hline Mean & 3815 & 390 & 1479 & 118 & 38.0 \\
\hline
\end{tabular}

Table 5: Fish mortality due to disease in four districts during July2008 to June 2009

\begin{tabular}{|l|c|c|c|l|}
\hline $\begin{array}{c}\text { Type of Disease } \\
\text { /other factor }\end{array}$ & $\begin{array}{c}\text { Mortality of } \\
\text { fingerlings (\%) }\end{array}$ & $\begin{array}{c}\text { Mortality of } \\
\text { adult fish (\%) }\end{array}$ & $\begin{array}{c}\text { Average } \\
\text { Mortality of fish } \\
\text { (\%) }\end{array}$ & More affected fish \\
\hline Bacterial disease & 30 & 68 & 49 & Adult fish \\
\hline Fungal disease & 20 & 40 & 30 & Adult fish \\
\hline Protozoan disease & 60 & 50 & 55 & Fingerlings \\
\hline Monogenean & 64 & 52 & 58 & Fingerlings \\
\hline
\end{tabular}




\begin{tabular}{|l|c|c|c|l|}
\hline $\begin{array}{c}\text { Type of Disease } \\
\text { /other factor }\end{array}$ & $\begin{array}{c}\text { Mortality of } \\
\text { fingerlings (\%) }\end{array}$ & $\begin{array}{c}\text { Mortality of } \\
\text { adult fish (\%) }\end{array}$ & $\begin{array}{c}\text { Average } \\
\text { Mortality of fish } \\
\text { (\%) }\end{array}$ & More affected fish \\
\hline Crustacean & 35 & 45 & 40 & Adult fish \\
\hline Malnutrition & 10 & 16 & 13 & Adult fish \\
\hline $\mathrm{O}_{2}$ deficiency & 40 & 30 & 35 & Fingerlings \\
\hline Water pollution & 33 & 25 & 29 & Adult fish \\
\hline Mean & 36.5 & 40.75 & 38.62 & \\
\hline
\end{tabular}

The losses occurring due to diseases in aquaculture systems sometimes can be very frustrating especially to the rural poor and small scale fish farmers. Economic losses due to fish diseases could be as high as Tk. 26,817/ha/year and average disease control cost was Tk. 2,905/ha/year (Faruk et al, 2004). Mohan (1999) reported those ectoparasites, protozoan, monogenetic trematodes, fish lice, endoparasitic protozoans are some of the very important pathogens that have had significant impact on the yield in carp hatcheries and seed production centers in India. Perhaps parasite acts either as a pathogen or vector for diseases (Roberts et al., 1986). Hossain et al. (1994a) reported that highest mortality of carp fingerlings were reported from nurseries infected with protozoan and monogenean parasites. Fish fry at the young stage become more susceptible to pathogen because of their immature immune system (Anderson, 1974), which support the present findings. Assistance of farmers from Government and non-government sectors on fish health management are very rare. There is a risk to livelihoods of fish farmers and fishermen from fish disease and fish health problems. Rural farmers were mostly resource poor with little or no knowledge of health management and had inadequate opportunities to improve management skills. Their ability to respond effectively to fish disease problem was also very limited. As a result, they suffered from financial losses due to fish disease. So prevalence offish diseases had negative impacts in fish production. About $14 \%$ of the actual production could be loss due to fish disease (Faruk et al. 2004). Fish farmers have been utilizing pesticides to control Argulus infestations. Due to indiscriminate use of pesticides, the pond environment has been deteriorating affecting the productivity of pond adversely (Ahmed 2004). It was observed that the Bangladeshi farmers are using pesticides excessively as a quick treatment for the Argulus sp., which is posing a major threat for sustainable carp culture development in the country. The pesticide is not only killing the Argulus but also affecting the abundance of crustacean planktons and many other non-target species (Ahmed 2004). Prolong use of pesticides in the ponds may create environmental hazards which may lead to threat to the consumers. Disease reduces growth and survivability of fish, which reduces reproduction of fish and hence lowers the fish population. Ultimately this leads to loss of fish production.

When much mortality of fish occurs due to the presence of epizootic, every attempt must be made to collect and destroy the dead fish. When the wastewaters pollute the watercourse, the physic-chemical parameters deteriorate and fish diseases occur. A sample of the water should be taken and analyzed 
chemically when fish die without showing any definite macro- or microscopical symptoms of disease. For a concrete diagnosis fixed material and cultures should be forwarded to the nearest Fish Pathology Laboratory. The address of the appropriate Fish Disease Laboratory may usually be obtained from the Department of Fisheries. The competent authorities of the nearest Fish Pathology Laboratory should be consulted for a definite ruling on the question, in case of any doubt as to what decision should be taken with regard to fish disease. Have to control water level fluctuation, aquatic vegetation, organic debris and water pollution. Water quality check, prevention of algal bloom and control of $\mathrm{O}_{2}$ depletion should be maintained. Different size and age groups of fish stocking should be avoided. Fish health management should focus on the development of strategies for farm-oriented primary health management packages including mobile diagnostic centers. The farmers and the extension agents should be trained up on simple diagnostic procedure and effective therapy and awareness creation among the farmers. There should be legislation on the safe use of the chemotherapeutic agents in fish disease prevention and control. With proper health management practices, the country can be saved from the economic losses caused by health problems in fisheries resources. Enough facilities regarding fish disease research should be provided to the educational institutions. Stocking of healthy and disease free fingerlings should be maintained properly. Proper stocking density of healthy fish, their right feed in optimum doses and right feeding time should be maintained.

\section{REFERENCES}

Amlacher, E., 1961. "Die Wirkung des Malachitgruns auf Fische, Fischparasiten (Ichthyophthirius, Trichodina), Kleinkrebse and Wasserpflanzen”, Dtsche, Fisch, Ztg., 8

Anderson, D.P., 1974 Fish Immunology. In: Diseases of fishes edited by Stanisias, F. Sneiszko, F. and Axelrod. H.R.F.H. Publication Inc. New Jersey 07753 USA

Ahmed A. T. A., 2004. Development of environment friendly measures for the treatment of Argulosis in carp brood ponds. Bangladesh J. Fish (Special issue), 27:3

Chowdhury, M. B. R., 1993. Research Priorities for microbial fish disease and its control in Bangladesh. Proceedings of the workshop on Research Priorities in Bangladesh for fish health. Disease prevention and Pathology, May 17, edited by A. Tollervey. Pp 8-11

Dogiel, V.A, 1961. Ecology of the parasites of fresh water fish in parasitology of fishes. Oliver and Bayd, London. pp 1-47

Hossain, M. A., A.N. H. Banu., m. H. Khan and N. Sultana, 1994a. Bacterial microflora isolated from carp and catfish fry and their sensitivity to some antibiotics. Bangladesh J. Microbios., 11 (2):95-101

Mohan, C.V. 1999.Social and Economic Impacts of aquatic animal health problems in Aquaculture in India. Paper presented at the Aquatic Animal Health Care in Rural Aquaculture, Dhaka, Bangladesh. 